\title{
A Quadruple and Quintuple Helix Approach to Regional Innovation Systems in the Transformation to a Forestry-Based Bioeconomy
}

\author{
Ida Grundel $^{1} \cdot$ Margareta Dahlström $^{1}$
}

Received: 15 June 2016/Accepted: 9 September 2016 /

Published online: 28 September 2016

(C) The Author(s) 2016. This article is published with open access at Springerlink.com

\begin{abstract}
This article aims to understand the possible preconditions for the transformation of a regional innovation system (RIS) into a quadruple and quintuple helix system applied to the development of a sustainable forestry-based bioeconomy in Värmland, Sweden. Research points to the necessity not only of further developing current innovation systems to include more actors than earlier but also of taking concern for the environment as a way towards attaining sustainability. The research was carried out in response to the need to understand the fourth helix and its role in RIS and to transform to a sustainable bioeconomy, as identified by researchers, policymakers and industry representatives. This study was inspired by participatory transdisciplinarity and a transdisciplinary research design, acknowledging the importance of a variety of actors in knowledge production from different spheres of society. Much of the empirical material gathered for this research was based on interviews and a workshop with different stakeholders. The results show that the use of a quintuple helix RIS in Värmland for the transformation to a forestry-based bioeconomy could be a possible way forward towards sustainability. The model proposes that involvement of civil society in the innovation system could contribute to a larger societal transformation that aims to change consumer behaviour, production patterns, technological developments, infrastructure, norms and values. However, the involvement of civil society in the innovation system must still be regarded as part of a vision statement in regional policy documents.
\end{abstract}

Ida Grundel

ida.grundel@kau.se

Margareta Dahlström

margareta.dahlstrom@kau.se

1 Department of Geography, Media and Communication, Karlstad University, Universitetsgatan 1, 65188 Karlstad, Sweden 
Keywords Regional innovation systems · Quadruple helix · Quintuple helix · Civil society $\cdot$ Bioeconomy

\section{Introduction}

Climate change, globalization and economic crises are new challenges facing us on different geographical scales, from the regional and national to the supranational level. Environmental problems are becoming more complex, uncertain and multiscalar, affecting a variety of actors and agencies, demanding new technical solutions, societal transformation and new collaborations. A transformation into a more sustainable society calls for a larger transition of societal functions, including new innovations in technology, regulations, production and consumer patterns, values and norms and supply networks (Geels 2005). It also requires a variety of knowledge and values in decision-making processes. However, the implementation of new forms of government and governance creates a complexity of networks stretching over different sectors and geographical areas. To some extent, policy-making processes have moved into new spheres and involve other actors; for example firms, supranational organizations and expertise have been given more influence (Miller and Rose 2008). This is also seen as a hollowing out of the state, as well as a managerial form of governance based on principles of new public management (Swyngedouw 2005; Sassen 2013). Because of the involvement of new actors in policymaking, it has become more difficult for citizens to engage in political processes (Mouffe 2008), whereas citizen-based knowledge is often seen as diffuse and difficult to embed in policy-making processes (Isenhour 2011). Nevertheless, public participation is emphasized as a democratic right by both environmentalist and pressure groups (Reed 2008) as well as at the supranational level by international organizations. At the European level, inclusive growth is seen as an important driver for the transformation of society (European Commission 2010). This is specifically pointed out, for example in the smart specialization platform (Foray et al. 2012) and in the European bioeconomy strategy (European Commission 2012), where the inclusion of civil society in an open dialogue is singled out as important throughout research into processes of innovation. At the supranational level, the United Nations points to a more inclusive approach towards a sustainable future in the new agenda of Transforming our world: the 2030 agenda for sustainable development agreed upon after the 2015 Paris summit, by empowering different actors and stakeholders in society (United Nations 2015).

The transformation into a sustainable society requires new challenge-driven innovations and new collaborations between more actors than earlier from different spheres in society with a variety of knowledge and practices, including civil society. Reed (2008) also stresses the importance of including different stakeholder groups in environmental decision-making processes. Environmental problems are complex and uncertain, stretching over different geographical scales and institutions. Thereby, the incorporation of different stakeholders and interest groups in policy-making processes can be a way of creating durability in the decisions made. However, if the participatory process is not handled well, it can create a feeling of disillusion among different groups seeing their claims not being realized. In relation to citizen participation in planning processes, although there is a broad field of research and literature (see for example 
Arnstein 1969; Healey 1997, 2003; Flyvbjerg 2003), there is a lack of research about the role and involvement of civil society in innovation systems and larger transformation processes. Therefore, here we address this gap by further developing the understandings and meanings of civil society - a fourth helix - in a regional innovation system (RIS) applied in a forestry-based bioeconomy in Sweden.

In 2012, the European Commission (EC) produced a strategy for the development of a European bioeconomy (Innovating for sustainable growth: a bioeconomy for Europe), which aims to transform the European economy into becoming more sustainable. From a European context, the focus is on "the production of renewable biological resources and the conversion of these resources and waste streams into value added products, such as food, feed, bio-based products and bioenergy" (European Commission 2012: 3). Thus, the European Union (EU) sees the bioeconomy as a two-pronged way of creating a more sustainable European economy; first by becoming fossil fuel free and second by turning the economy into a circular economy building on renewable resources. Further, the European bioeconomy is linked to the European Smart Growth strategy, innovation policy, resource efficiency and the strengthening of the European market. Several of the regions in Europe have directed their smart specialization strategies, namely research and innovation strategies, towards the development of a sustainable bioeconomy in one or several industrial sectors. Thus, the discussion about both the bioeconomy and smart specialization strategies is closely linked to innovation policy. There are also connections between the development of national strategies on the bioeconomy and the recommendations made by the Organization for Economic Cooperation and Development (OECD) in the 2009 report The bioeconomy to 2030: designing a policy agenda (OECD 2009).

It is important to emphasize that the meanings of the word "bioeconomy" as well as the phrase "bio-based economy" differ slightly and that their actual meanings are problematic because of vague definitions (Staffas et al. 2013). The definition of bioeconomy varies across different parts of the world. In the European context, there is a greater focus on biomass and its waste streams as a resource when transforming into a more sustainable society and a circular economy; in contrast, the OECD and the USA do not have an explicit sustainability agenda and the concept is mainly used to describe the conversion of raw material into products in biotechnology and the life sciences (Grundel and Dahlström 2015). In this article, we will use the term bioeconomy with reference to a sustainable bio-based economy with the aim of transforming society as a whole into becoming more sustainable. Thus, bioeconomy refers not only to economic activities but also to all of society. Transformation ${ }^{1}$ into a bioeconomy covers several areas of society including changes in consumption and production patterns, a transition from the use of fossil materials to sustainable materials, as well as a change of waste streams into a circular economy. It has been argued that bioeconomy is just another buzzword for sustainable development and a "greening of the economy" (see e.g. Birch et al. 2010; Birch 2012). In Europe, this can be seen as a result of marketization and the development of new products in food, animal feed, biobased products and bioenergy (European Commission 2012) to enhance the

\footnotetext{
${ }^{1}$ In this context, although we use the word "transformation", another possible theoretical concept is "transition", in that the transition theory emphasizes larger system innovations such as a shift from one sociotechnical system to another (Geels 2005; Geels and Schot 2007; Geels 2010).
} 
competitiveness of the EU. Similarly, Kenis and Lievens (2014) highlight how environmentalist claims can be depoliticized because of the power of elite groups that shape the agenda of sustainable development by the introduction of new concepts such as "green economy" and bioeconomy. This might contribute to the exclusion of certain groups in policy debates about sustainability. However, other scholars (see e.g. Campbell et al. 2015; Carayannis et al. 2012) use the concept of "quadruple helix" as a way of broadening and opening up former relatively closed policy-making processes and innovation systems, thereby making them more democratic. Earlier innovation systems such as the "triple helix" based on collaboration between universities, government and industry (Leydesdorff and Etzkowitz 1996; Etzkowitz and Leydesdorff 2000) should also include a "fourth helix" - civil society - and thereby create a quadruple helix model. Carayannis and Rakhmatullin (2014) also point to the importance of expanding existing definitions of democracy to include not only political and civil rights but also sustainable development. In this context, they developed the concept of the triple helix innovation system into not only a quadruple helix system but also a "quintuple helix" system, where the fifth helix represents the environmental settings of a specific region. Thus, the broadening of the former innovation system includes perspectives of both democracy and environmental concerns. Carayannis et al. (2012) also saw the quintuple helix model as a way of stressing the transformation of society and the current economic system into becoming more sustainable. The development of a more advanced bioeconomy requires not only a shift in society in general but also a transformation in environmental policies. Strategies and policies used for the transformation of current economies into a sustainable bioeconomy can be seen as a way of coordinating transformation by means of protecting biodiversity, food quality and quantity, preserving biotopes and mitigating climate change. However, current national strategies and policies are used to a great extent as a way of increasing economic growth by the invention of new products, system innovations and the growth of new markets and new employment (Staffas et al. 2013). Therefore, the model of a proposed quintuple helix system is interesting from the perspective of new environmental challenges and transformation to sustainability.

The aim of this article is to deepen the understandings of, and preconditions for, the transformation of an RIS into a quadruple and quintuple helix system applied to the development of a sustainable forestry-based bioeconomy in Värmland, Sweden. We address this with the following research question: In which ways can the further development of a regional innovation system contribute to a transformation to a forestry-based bioeconomy?

\section{Outline}

First, an overview of theoretical considerations about different forms of RIS is given, followed by a discussion of the concepts of quadruple and quintuple helix systems. The research design and methodology are then presented, and we describe the case study that was conducted. The possible development of a quadruple and/or quintuple helix system in the region is then analysed and discussed, followed by our concluding remarks. 


\section{Non-Inclusive Innovation Policy and Regional Innovation Systems in Europe}

Innovation policy is mainly driven by economic growth and economic development agendas, where new innovations are seen as drivers of economic growth and development. In this way, innovation policy is used as an important tool for governmental institutions to enhance and support innovations on different geographical scales to promote economic growth (see e.g. Asheim and Coenen 2005; Pettersson 2007; Lindberg 2010). One important part of this development is the notion of an RIS, which started to gain attention in the early 1990s. The idea of an RIS is closely linked to the rise of regional clusters and regional innovation policy where the regional level is seen as the appropriate geographical level for applying innovation policy, in contrast to the previous forms of innovation policies focussing on a national level (Lundvall 1992). In this context, an innovation is the outcome of social processes where the innovation process occurs in interactions between different actors. In regional science, the outcome of an innovation process is closely related to the geographical-in this case regionalcontext and institutional settings ${ }^{2}$ (Doloreux and Parto 2005). Therefore, an RIS can be seen as an institutional infrastructure put in place to support innovations in firms in a specific region (Asheim 2007). Until now, innovation policy aiming to support innovation systems has mainly been dominated by a triple helix composition, building on cooperation between universities, government and industry (Leydesdorff and Etzkowitz 1996; Etzkowitz and Leydesdorff 2000; Westlund 2006).

Today, there is an enhanced focus on the RIS concept because of the EC directive for European regions to develop so-called Research and Innovation Strategies for Smart Specialization (RIS3). Regions around Europe now develop smart specialization strategies to draw on their own unique resources to receive funding from European structural funds (Aranguren and Wilson 2013; Carayannis and Rakhmatullin 2014). Smart specialization strategies mainly build on strengthening preexisting specializations at the regional level with the aim of reaching the European 2020 goals in research and innovation (Carayannis and Rakhmatullin 2014).

\section{Critical Perspectives on RISs}

Earlier dominant innovation policies were characterized by a linear view, with a main focus on product development and push/supply-driven high-technology policy. The role of science in this context has been perceived as the base for technological development and new products, mainly satisfying the market and the commercialization of new products. In this way, innovation is seen as knowledge owned by talented individuals and/or research groups (Arnkil et al. 2010). In the innovation literature, this is also seen as an expression of more traditional forms of knowledge production called mode 1 (Carayannis and Campbell 2009; Lindberg et al. 2012; Carayannis and Campbell 2012). The second generation, mode 2 innovation policies, can be seen as

\footnotetext{
${ }^{2}$ This definition also relates to the idea of a cluster as "a geographically proximate group of interconnected companies and associated institutions in a particular field, linked by commonalities and complementarities". Clusters do not necessarily consist of only firms and industries but can also include institutions, authorities and research institutions (Porter 2000: 254).
} 
an opening up of innovation processes with a broader understanding of innovations not only as goods and products but also as services, ideas and practices (Rogers and Shoemaker 1971). Consequently, innovation processes started to include more actors than before, as in the development of the triple helix model in innovation policy (Nählinder 2012). The third generation of innovation policy, mode 3, is closely linked to the second generation, but includes not only other sectors than just heavy industry, such as services and healthcare, but also new forms of innovations in services, organizational and user-driven innovations (Nählinder 2012). Cooke (2007) also stressed the importance of the wider setting for triple helix relations. Within the framework of constructed advantage, he argued that the public factor of community and culture-cosmopolitanism, sustainability, talented human capital, creative cultural environments and social tolerance-provides an exemplary background for triple helix interactions. These latter forms of innovation policies where more actors are included in the innovation process can also be seen as an expression of multilevel governance and new regional growth policies in the EU (Lindberg et al. 2012).

At the same time, innovation policies have been criticized as being too narrowminded and undemocratic. There has also been criticism of the triple helix system as building upon links to the clustering of heavy industries in specific regions often dominated by men, thereby also transmitting specific values and norms about entrepreneurship and innovations as masculine activities. A number of studies have highlighted the gap between gender equality, innovation policy and entrepreneurship (see for example Lindberg et al. 2012; Lindberg et al. 2014), which in turn can be related to more general perceptions about gender in society where entrepreneurial and innovative activities are perceived as masculine (Pettersson 2007). In this way, innovation and entrepreneurship policies can work to exclude specific groups in innovation and entrepreneurial processes (Lindberg et al. 2014), thereby perpetuating a number of inherent problems linked to gender, social class and ethnicity, and maintaining elitist approaches to innovation, excluding civil society as a whole.

Alsos et al. (2013) highlighted the lack of studies on gender, innovation and entrepreneurship, suggesting that this also contributes to gendered ideas about innovation and entrepreneurship. Appelstrand and Lidestav (2015) pointed to the economic benefits of including former excluded groups in innovation processes by contributing to new ideas, norms and values in earlier male-dominated settings, thereby leading to new businesses, services and products. It is also important to emphasize democratic aspects of the involvement of civil society in different types of RIS. We address this by highlighting the importance of the inclusion of a fourth helix in forms of RIS to open them up for more actors and the inclusion of civil society. Recent debates in research on RIS (see e.g. Carayannis and Campbell 2012; Hock Heng et al. 2012; Carayannis and Rakhmatullin 2014; Lindberg et al. 2014) emphasize that more stakeholders should be included in innovation policies, turning the triple helix model into a quadruple one by including civil society as a way of democratizing innovation processes. Moreover, in the following sections, we also emphasize the importance of the development of a quintuple helix system, addressing the concerns of environmental aspects and a transformation of society into becoming more sustainable (Carayannis and Rakhmatullin 2014). 


\section{Towards Inclusive Innovation Policies in RISs in Europe}

In general, innovation policy in Europe is changing. The move from a triple helix to a quadruple helix system has not only been visible in the research and innovation literature. The term quadruple helix and the importance of a wider community in addition to the university-industry-government nexus for innovation are also stressed by policy actors (Dahlström and Hedin 2010). In the European RIS3 - working to provide information, methodologies and expertise about smart specialization in the European regions - it is recommended that participation should be wider than in the earlier triple helix model, which is seen as insufficiently inclusive because of broad definitions of innovation processes. A range of actors, from innovation users or other groups representing consumers, non-governmental organizations (NGOs), citizens and workers, are all addressed to be involved in the RIS3 process (Foray et al. 2012: 21), building on the principles of a quadruple helix system.

\section{Quadruple Helix}

A quadruple helix system must be seen as a widening of the triple helix system by including a fourth helix - civil society - in the innovation system. A wide range of possible definitions of a fourth helix can be applied in policy as well as in research. Starting from a more democratic perspective, the fourth helix can be defined as including citizens, NGOs, labour unions and others to more growth-oriented perspectives as consumers and users. In a democratic manner, the fourth helix can be exemplified by NGOs representing individuals with other interests than purely economic ones, for example environmental and social aspects of society (Hock Heng et al. 2012). The more growth-oriented perspectives mainly see the public as users and/ or consumers or as entrepreneurs singled out as being vital to growth and economic development (Martinez and Palazuelos-Martínez 2015). In this context, civil society can become a resource for markets, firms and commercial activities, and as a way for firms to adapt to market demands without the risks involved in product development (Arnkil et al. 2010). User-oriented or -driven innovation is thus a process in which users and user communities are given more importance for success in business and in commercially successful innovations. However, user-driven innovation must be regarded as more democratic than other innovation processes due to the inclusion of users in the actual innovation process (von Hippel 2005). This orientation towards userdriven innovation is also important in the public sector for renewal of public services, and an emerging approach is to widen innovation policy to include non-technological innovations in services and the creative industries, and not just heavy industry ${ }^{3}$ (Arnkil et al. 2010). Furthermore, consumers have long been underestimated or ignored in innovation processes, even though they must be seen as the main users of goods and services (Ivanova 2014).

\footnotetext{
${ }^{3}$ Other examples of user-driven innovation are living labs functioning as public-private partnerships, where universities, government, industry and citizens work together in co-creation processes. The purpose of a living lab is to involve users in a "real-life context", validating products and services (Arnkil et al. 2010). According to Bergvall-Kåreborn and Ståhlbröst (2009), a living lab works in three ways: as an environment (i.e. platforms and user communities), as a methodology (i.e. methods for user involvement) and as a system.
} 
Carayannis and Campbell (2012) defined the fourth helix in two ways. In the first, culture and media include aspects such as culture and innovation culture, values and lifestyles, multiculturalism, media, arts and art schools as important parts of the innovation system. In the second, the inclusion of civil society in innovation and knowledge production can be seen as a tool for enhanced democracy in innovation processes. It is also a way of enhancing access to different governmental and academic resources for less favoured groups (Lindberg et al. 2012; Lindberg et al. 2014). The fourth helix can also be seen as an arena that is wider than the family, the state, firms and businesses, where people come together with a common interest or goal. In this context, civil society must be seen as separate from universities, governmental institutions and industries in a triple helix system (Yang and Holgaard Egelund 2012). According to Carayannis and Rakhmatullin (2014: 220), another difference between the traditional triple helix system and the development of a quadruple helix system is the top-down perspective in the triple helix system, while the inclusion of civil society points to a bottom-up perspective. Similarly, Wallin (2010) argued that former and current triple helix systems must be updated to include NGOs, local and regional communities and societies in technological development processes and thereby work in favour of a participatory approach to regional innovation processes.

\section{Quintuple Helix}

Whereas a triple helix can be seen as the core embedded in a quadruple helix system, Campbell et al. (2015) developed the innovation model further into a quintuple helix system where the fifth helix represents the natural environment of society. According to Carayannis et al. (2012), the quintuple helix model comprises five helices: the education system, the economic system, the natural environment, the media- and culturebased public and the political system. These helices also comprise the earlier triple helix model in that the education system is represented by academic and higher education organizations, the economic system comprises industry, banks and services and the political system represents the public authorities and their plans, laws, ideas and so on. These five helices work as "subsystems" in which knowledge moves from subsystem to subsystem in a circular manner. If knowledge is input into one subsystem, a process of knowledge creation leads to new knowledge or innovations. That does not mean that the fifth helix is an actual actor but rather a driver for new knowledge and innovations in response to environmental challenges.

The progression of this model can be related to the development of a knowledge society. In this model, the triple helix system relates to the knowledge economy, the quadruple helix to the knowledge society and knowledge democracy and the quintuple helix to a broader perspective of socioecological transformations and natural environments (Carayannis et al. 2012). Carayannis and Campbell (2009, 2010) saw the importance of natural environments and the quintuple helix model as a way towards sustainable development and social ecology that is the relationship between society and nature and their coevolution. In this way, the expansion of the triple helix model to include a fourth and fifth helix is interesting in relation to a transformation of society to a forest-based bioeconomy. The quintuple helix innovation system is problem oriented and aims to function as a way towards socioecological transformation that is the transformation of society to a bioeconomy or a circular economy and thereby towards 
sustainability (Carayannis et al. 2012). In this system, based on a close dialogue with citizens, innovation goals and strategies should be able to integrate public opinion into issues concerning knowledge creation, creative industries, politics, lifestyles, culture, values and art (MacGregor et al. 2010). Furthermore, the quintuple helix model is seen as a way of tackling possible challenges linked to global warming, where knowledge and knowledge production are bound to specific subsystems such as, for example the regional level. Thereby, the quintuple helix system can be used as a model to understand the relationship between knowledge and innovation contributing to the development of sustainable development. In any process of transformation, knowledge is the fundamental resource (Carayannis et al. 2012). Knowledge is the outcome of what Carayannis et al. (2012: 3) see as "creative processes, combinations, and productions in so-called 'Knowledge models' or 'Innovation models'”. The abovementioned innovation models of modes 1 to 3 are the predecessors of the quintuple helix model and embrace a socioecological perspective. By including the environment or the natural settings of a certain place, region or country and its importance in the innovation system, the evolvement of society is based on coevolution between society and nature. The circulation of knowledge not only in a quintuple helix system is the main component of the model because of its stimulation of new knowledge in each subsystem but also in the system as a whole (Carayannis et al. 2012). This in turn can be implemented in the transformation into a forestry-based bioeconomy. Further, this is grounded on socioecological principles and works as a driver for new innovations, knowledge production and a transformation to a more sustainable society. The aim of the quintuple helix model is to establish nature as a central component for innovation and knowledge production (Carayannis et al. 2012), and the model is the pivotal force and driver for progress. It grasps and specializes on the sum of the social (societal) interactions and the academic exchanges in a state (nation-state) to promote and visualize a cooperation system of knowledge, know-how and innovation for more sustainable development (Carayannis and Campbell 2010: 62).

\section{Research Methodology and Design}

The research reported here was carried out in response to a need identified by researchers, policymakers and industry representatives. This need relates to the concept of the quadruple helix and to how one can understand the fourth helix and its role in RISs and a transformation to a sustainable bioeconomy. These questions surfaced in an international workshop called "Developing Cross-Cutting Stakeholder Involvement for Realizing the Bioeconomy" that was held in Sweden in November 2014, where triple helix representatives came together with the aim of identifying key research and development questions for a transition to a sustainable regional development in a bioeconomy. The workshop succeeded in generating preliminary research questions dealing with themes such as a quadruple helix and actors within the fourth helix and with development themes such as the links between bioeconomic and regional development policies and the implementation of such policies, for example through RISs. The research was thus inspired by a transdisciplinary research design acknowledging the importance of a variety of actors in knowledge production from different spheres of society (Mobjörk 2010). A transdisciplinary approach is often used in needs-driven 
research, such as in this case, and it is important in research on collaboration and stakeholder involvement. Here, the focus was on the development of a quadruple helixtype RIS. This model can be seen as recognizing a more participatory design because of the importance of more stakeholders to be included in RISs and knowledge production. This is also promoted in the definition of transdisciplinarity, which according to Mobjörk (2010: 866), "can be understood as an extended knowledge production process including a variety of actors and with an open perception of the relevance of different forms of information produced by the scientific and lay community".

It is possible to differentiate between participatory and consultative transdisciplinarities. The participatory approach covers participation from different stakeholders during the research process, whereas the consultative approach comprises a limited number of actors mainly giving later feedback (Mobjörk 2010). The methodology in the research reported here was principally inspired by participatory transdisciplinarity. The respondents are thus not only the subjects of study, but are also given the possibility of forming part of the research project as a whole. The key is to maintain a close, dynamic and equal relationship between researchers and other stakeholders. Another aspect is the importance of knowledge transfer between different actors in the research process, closely linked to areas in participatory research, participatory planning and social learning. Normally, social learning is used from a normative point of view; however, it has become increasingly common in sustainability research to use knowledge from civil society to learn from and about customs, values and habits where "joint knowledge production and mutual learning of science and society are necessary to foster the transition to a sustainable society" (Hage et al. 2010: 256).

At this point, we need to raise two points of methodological criticism against our research. The first relates to the fact that although the research takes its point of departure in a participatory transdisciplinary perspective where the workshop on triple helix participation identified a common need to be addressed, members of a fourth helix were not included from the start of the research that followed (see further below). The second point is linked to the roles that we as researchers have in the triple helixtype RIS of Värmland. Parallel to the research, the authority Region Värmland led the work with the development of the regional smart specialization strategy Värmland's Research and Innovation Strategy for Smart Specialization 2015-2020 (Region Värmland 2015). This work involved a number of actors from the entire triple helix spectrum, and in our case, we were involved both in workshops and by giving comments on drafts of the strategy. Thus, we contributed to the inclusion of the issue of a quadruple helix in the strategy, where the following was stated under the theme of research and innovation that are needed: "Develop research related to how it is possible within bioeconomic efforts to include and take advantage of expertise and perspectives from regional players in a quadruple helix spectrum. In other words from both women and men and within the organized civil society" (Region Värmland 2015:27). Having raised these methodological caveats, we argue that they do not make our research and the results less valid. Indeed, we claim that they are part of doing transdisciplinary research that aims to contribute knowledge to society and to develop methods for participatory research, which in this case explicitly deals with the inclusion of a fourth helix.

The empirical material in the research is mainly based on interviews with different stakeholders from policymakers at the regional level in Värmland, representatives of the forestry-based industry and the cluster organization The Paper Province, as well as 
representatives from a potential fourth helix such as different NGOs. In addition, a workshop with participants from academia, regional and local authorities, industry and NGOs in the region was held in September 2015. Different actors were invited to participate in the workshop, also representing the four helices in a possible quadruple helix system. In this kind of participatory research approach, the point is to develop further knowledge about specific issues collectively (Lindberg et al. 2012). In this case, the aim was to develop further knowledge about European policy, bioeconomy, smart specialization and the role of civil society in transformation processes, and more specifically in Värmland. One important theme was the role of civil society and its meanings in the transformation into a sustainable bioeconomy in a forestry context. Documents such as the smart specialisation strategy or the VRIS3 in Värmland and EU and national policies were also analysed.

\section{Bioeconomy, RISs and Smart Specialization in Sweden and Värmland}

In Sweden, there is no national strategy for the development of a possible bioeconomy. However, a definition that can be used in a Swedish context is found in the 2012 document, Swedish Research and Innovation Strategy for a Bio-Based Economy, produced by Formas, ${ }^{4}$ Vinnova $^{5}$ and the Swedish Energy Agency": "The conversion to a bio-based economy means a transition from an economy that to a large extent has been based on fossil fuels to a more resourceefficient economy based on renewable raw materials that are produced through the sustainable use of ecosystem services from land and water" (Swedish Energy Agency et al. 2012: 9).

This definition calls for a larger transformation of society. According to Geels (2011: $24)$, this can be seen as a systemic change often called "sociotechnological transitions" because they refer to larger societal changes in, for example transportation systems, consumer and production patterns, food systems, technological changes, cultural and scientific knowledge. Societal transformations must also be seen as long-term processes including a wide range of actors. However, the strategy does not have any direct influence on the development of a common bioeconomy in Sweden. Nevertheless, the regional authorities in Värmland, as a result of the EC directive to develop smart specialization strategies, have developed an RIS3 pointing to the bioeconomy as a main priority in the region (Region Värmland 2015). Värmland is a county with a long history within the steel and timber industry, which in turn has led to the ambition to develop a forestry-based bioeconomy. In this case study, we have chosen to concentrate on specific parts of the VRIS3 in Värmland linked to the development of a forestrybased bioeconomy in the region.

\footnotetext{
${ }^{4}$ Formas is the Swedish Research Council for Environment, Agricultural Sciences and Spatial Planning.

${ }^{5}$ Vinnova is the national innovation agency in Sweden working under the Ministry of Enterprise, Energy and Communications. Its aim is to promote sustainable growth by improved conditions for innovation together with funding for challenge-driven research.

${ }^{6}$ The Swedish Energy Agency works for a sustainable energy system by combining ecological sustainability, competitiveness and security of supply. It also finances research for new and renewable energy technologies, fuels and vehicles.
} 


\section{Developing an RIS in Värmland}

According to Bjurulf and Olsson (2010), the development of the RIS in Värmland started in the early 1990s. It was formed around different cluster initiatives and innovation platforms, strongly driven by firms and industries not only in the region but also in cooperation with the university and the regional authorities in a triple helix system. Hospers et al. (2008: 443) saw this model in a Swedish context as an industryscience cooperation model where cluster policy works in two ways: directing public investments to provide clusters with critical mass and creating links between industry and science in the region.

In Värmland, one of the earliest cluster initiatives was The Paper Province, ${ }^{7}$ established as a member organization for firms in the pulp, paper and machinery sector in 1999. According to Malmberg and Power (2006), a cluster initiative can be seen as a policy tool, aiming to identify a specific cluster and create self-awareness about its existence, sometimes by giving it a name and/or a brand to create an identity (Hospers 2005). The cluster organization The Paper Province can be seen as a brand for the paper industry in the region, but with approximately 100 members in the entire value chain, it mainly serves as a member organization coordinating firms and industries in a "geographical cluster" of forestrybased industries to strengthen their growth and competitiveness. The cluster organizations in Värmland have also gained support from the regional development authority, Region Värmland. Therefore, the definition of the cluster organizations in Värmland can be linked to situations where, for example regional policymakers identify a cluster or different clusters in their region to enhance the effects of their existence (Hospers 2005).

\section{The Paper Province 2.0}

In 2001, the Swedish innovation agency Vinnova presented a programme (Vinnväxt) in which Swedish regions competed for funding over a period of 10 years. The aim was to promote sustainable growth in Swedish regions by developing competitive research and innovation environments. Since its inception, 15 functional regions have been awarded funding in this programme (Vinnova 2014). In 2013, The Paper Province 2.0 was declared a Vinnväxt winner by Vinnova with the aim of transforming the pulp and paper industry in Värmland into a forestry-based bioeconomy together with the other cluster organizations, public and private research and innovation environments (Vinnova 2014). The total funding in Värmland is SEK 130 million and is jointly cofinanced by Vinnova and a triple helix partnership consisting of the cluster organization The Paper Province and its member firms, the regional and local authorities in the region, Karlstad University, the SP Technical Research Institute of Sweden and the Swedish Forest Agency. The grant supports funding for research, the development and commercialization of new products and the further development of the RIS in relation to a forestry-based bioeconomy. The fact that Paper Province 2.0 was awarded Vinnväxtfunding had a profound effect on the smart specialization strategy of Värmland where the forest-based bioeconomy has become the specialization of highest priority.

\footnotetext{
${ }^{7}$ The other cluster initiatives at this time were the packaging arena, steel and engineering and compare in the IT sector. However, given our focus on the development of a forestry-based bioeconomy, the focus in this article is on the paper and pulp industry.
} 


\section{Smart Specialization and the RIS3 in Värmland}

In 2015, the regional development authority Region Värmland developed the RIS Värmlands Research and Innovation Strategy for Smart Specialization 2015-2020, which was organized together with other actors in the RIS from industry and Karlstad University. Currently, the RIS3 in Värmland builds on close collaboration between Karlstad University, the regional development authority and firms and industries in the region in a triple helix system. However, the strategy also highlights a broader inclusion of other actors compared with the traditional triple helix system by adding perspectives and expertise from civil society and citizens, already noted as important features for the further development of a bioeconomy in the region (Region Värmland 2015). It is also important to reiterate that the perspective of the involvement of civil society can be seen as a result of current research projects on the democratization of forms of RIS. The inclusion of civil society, clients and users in regional innovation processes is also recommended by the EC in its platform for smart specialization (Foray et al. 2012) and also influences the RIS3 in Värmland.

The innovation system that developed in Värmland in the beginning of the 1990s has been criticized as overly influenced by values from traditional and male-dominated industries. Forsberg and Lindgren (2010) argued that even though the earlier triple helix system that developed in Värmland aimed to be open to a variety of actors, it was a relatively closed system dominated by male settings due to its connections to firms and businesses in the steel, and paper and pulp industries. These are also the sectors that have been promoted and invested in by regional authorities (Forsberg 2010). Säll (2011) notes that although the "gendering" of cluster policy was present in the former regional development programme, in the end, it did not have any real impact on the innovation platform in Värmland. Gender is also an aspect included in the current RIS where it is clear that the export industries in the region are mainly dominated by men, which leads to the need to create a labour market that is attractive to both genders (Region Värmland 2015). The overarching goal in the RIS is service innovation or value-creating services in all prioritized areas, ${ }^{8}$ the main reason for which is that part of the service sector appeals to women, which then is believed to attract women to maledominated industries: "Parts of the service sector appeal to women. Servitisation enhances the appeal to women in male-dominated industries" (Region Värmland 2015: 18). Therefore, it is interesting that the focus in this RIS is still on maledominated settings rather than on the service sector.

The role of civil society in the transformation to a forestry-based bioeconomy in Värmland varies but mainly includes consumers, clients and users. In this way, the inclusion of civil society is connected to the development of new products in the bioeconomy. To a great extent, technological developments and solutions are highlighted as important by inventions and new products in wood processing.

Another role of civil society in this RIS is shown by the commitment in activities related to circular economies. Several actors representing civil society in Värmland

\footnotetext{
${ }^{8}$ The smart specializations in Värmland are divided into two groups: prioritized specializations and specializations under qualification. The prioritized specializations are as follows: forest-based bioeconomy, digitalization of welfare services and advanced manufacturing and complex systems. The specializations under qualification are as follows: nature, culture and place-based digitalized experiences and system solutions with photovoltaics (Region Värmland 2015).
} 
have taken the initiative to work in favour of a circular economy by the creation of new businesses and other activities. A sustainable bioeconomy could also be seen as part of a circular economy if it builds on closed waste streams and renewable resources. Thus, the participation of civil society can be seen in two, and to some extent, contradictory ways: as consumers and as committed and engaged citizens. Further, the regional authorities have developed a vision for the development of a forestry-based bioeconomy in the region, "to which people from all over Europe and the rest of the world come to learn about and witness the achievements possible when society, business, academia and the citizenry, women, men, girls and boys, come together for a common vision" (Region Värmland 2015: 24). The vision aims to include all sectors of society in the transformation to a forestry-based bioeconomy. However, there are no actual directives on how civil society is supposed to form part of the transformation, and until now, there has not been any involvement of civil society in the RIS. According to regional officials, this could be a direct result of a lack of cooperation with the municipalities in the region where the regional development authority does not have the power to act in specific local matters. In a study of 16 city municipalities and service providers, MacGregor et al. (2010) argued that there must be a readiness for the development of a quadruple helix system in a local innovation system. They found that a functioning architecture needs to be in place to support the further development of a quadruple helix system. Thus, a quadruple helix system is not necessarily the result of a well-developed triple helix system. It is rather the outcome of close relations between actors that drive innovation together with civil society. MacGregor et al. (2010) showed that it was mainly the municipalities with well-established connections with civil society rather than with service providers that were driving innovation. However, the links between civil society and the municipalities were not based on innovation or innovation policy. Rather, they were concerned with other important aspects - such as the development of strategic plans and local and regional visions that aimed to create a good life for its citizens - that are also important in the development of innovation policy (MacGregor et al. 2010).

In the Swedish national strategy for research and innovation for a sustainable biobased economy, there is also discussion about the importance of further research into civil society and into changed consumer behaviour and attitudes (Swedish Energy Agency et al. 2012). This is in line with research about stakeholder involvement aiming to empower different groups in society, especially the involvement of civil society (see e.g. Hage et al. 2010). It is also important to stress the different uses and users that must be taken into account in the development of a forestry-based bioeconomy, which can also lead to an increased production of biomass, resulting in consequences for other uses of land, forests and water that affect, for example the tourist industry, outdoor life and recreation, hunting and fishing and other organizations using the forests. Thus, a transformation into a bioeconomy can result in possible conflicts between different actors and interests (Edelenbos and Klijn 2006; Swedish Energy Agency et al. 2012). Broad stakeholder involvement can also lead to mutual learning and the empowerment of different groups in creating engagement from various actors in the transformation to a bioeconomy. Stakeholder involvement is also seen as strengthening the commitment in civil society to the process of sustainable development and transformation processes in general (Hage et al. 2010). Therefore, different kinds of knowledge are important in the transformation to a sustainable society, where cooperation between research 
institutes, public authorities and civil society plays an important role in knowledge production (Reed 2008).

\section{Exploring the Engagement of Civil Society in the RIS in Värmland}

When exploring the engagement of civil society in the RIS and in the transformation to a forestry-based economy, interviews and comments from participants in the workshop showed that the role of civil society in this process had not yet been defined. Although a possible process to include civil society in the RIS had only begun, important conclusions could be drawn from the interviews and the workshop. A point that was put forward in the interviews as well as in the workshop was the need for better communication between different actors. One aspect was the ability of the regional authorities to inform representatives from civil society about activities taking place at the regional level to enable them to participate in and influence policy processes, thereby leading to a more inclusive and open innovation system. This was also seen as a way of creating commitment and relevance within civil society for the transformation to a forestry-based bioeconomy. However, it was also interesting that representatives from civil society said that they had to invite actors from other sectors to their own meetings, workshops and other activities as a way to initiate a process of collaboration.

Another aspect regarding communication related to the issues at stake. Several of the stakeholders from civil society saw a problem with the concept of a forestry-based bioeconomy. The associations oriented towards environmental sustainability highlighted negative aspects linked to this form of bioeconomy because of its dependency on biomass instead of fossil materials. They would rather see the development of a circular economy, having clearer connotations to sustainability, or a more common definition to which different actors could relate. Other stakeholders did not have a former understanding of the meanings of a forestry-based bioeconomy, highlighting the importance of talking about "the forest" as a way of creating a common platform to involve different kinds of stakeholders.

There must also be a clear role for participation by civil society in the RIS. The interviews and comments from the workshop participants showed that their understanding of the concept of "civil society" differed between actors-associations and NGOs, "other" than academia, firms, businesses and authorities, users and customersas recipients of the bioeconomy. To some extent, the representatives from the forest industry in the region had problems seeing what the actual role of civil society could be. Specific examples of associations that were highlighted as a potential fourth helix in Värmland were mainly forest owners, such as the Church of Sweden, different kinds of forest associations, e.g. Skogskvinnorna ${ }^{9}$ and the Federation of Swedish Farmers. Only in one case was an environmental association mentioned. Rather, environmental associations were seen as problematic and working against the forest industry in Sweden. One respondent noted the risk that, when represented by environmental associations, the forest industry might regard civil society as activists and therefore as a threat to their firms, which might impede collaboration between different stakeholders in the RIS. However, this is also a potential problem within a triple helix-type

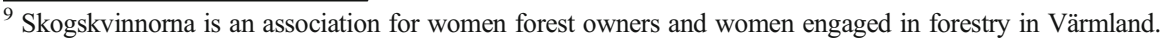


system where the different actors involved tend to have different aims and goals. Firms and businesses tend to build their judgements on market principles, governments on development and growth agendas, and academia on the exchange of ideas and knowledge (Westlund 2006). In contrast, civil society has not yet been included, but is likely to have a number of different agendas and perspectives. In interviews and in the workshop, some participants expressed a wider definition of civil society where all people living in the region have some sort of link to the forest and thereby have an interest in the development of a forestry-based bioeconomy. There are many users with interests in the forest and the forestry-based sector, such as the tourism industry, leisure and sport organizations, orienteering associations, scout movements and trekking associations. Some workshop participants also brought up groups often left out of decision-making processes, such as schoolchildren and university graduates, who are important for the future development of the region.

Other important aspects mentioned by representatives of civil society were the ways in which civil society and especially NGOs are changing in their form and shape. Younger people are no longer organized in the same manner as before. Today's organizations are shaped around new platforms and in virtual networks such as the Internet and Facebook (Fuster Morell and Subirats 2012). Other aspects noted by civil society representatives included time availability; commitment to NGOs typically involves voluntary participation after working hours, making it difficult to participate in daily activities and involve civil society if activities are not held in the evenings or after working hours. As noted, in the future, other solutions such as online platforms may help avoid these issues.

\section{Concluding Discussion}

In this article, we addressed the following question: In which ways can the further development of a regional innovation system contribute to a transformation to a forestrybased bioeconomy? The transformation to a sustainable society requires a change in both innovation and environmental policy to involve further stakeholders in innovation systems. This is in line with research calling for further stakeholders in RIS construction, transforming the triple helix system into a quadruple helix system. Furthermore, research and international policy point towards the importance of involvement from further stakeholders in environmental decision-making processes. This involvement can be seen not only as a democratic right but also as a way of creating durability and credibility in the decisions made. This also becomes important in the case of a transformation to a forestry-based bioeconomy, which is a process that will take many years. A transformation of this kind calls for a larger transition of societal functions and not just the economy, requiring knowledge from different spheres of society.

Two important aspects of the development of a quadruple or a quintuple helix system in Värmland can be highlighted. In this RIS, one of the prioritized areas is the development of a forestry-based bioeconomy. This can be seen as the development of a quintuple helix system where both the natural habitat in the region and the environment are taken into account in the development of the system (Carayannis and Campbell 2012; Carayannis and Rakhmatullin 2014; Campbell et al. 2015). However, the system is not yet fully developed because of the lack of involvement 
and participation of civil society in the innovation system. Several of the interviewed associations and organizations possess valuable knowledge about both forestry and the forest as such. Following Carayannis et al. (2012), the quintuple helix system is supposed to work as a chain of value creation, where all five helices are important for knowledge production and new inventions; however, in the case of Värmland, a working quadruple helix system has not yet been developed. Indeed, as noted by MacGregor et al. (2010), there is no actual support for the development of a quadruple helix innovation architecture based on a good working triple helix system. A wellestablished triple helix system may be a problem for the development of a quadruple helix system, because of the strong ties between the actors already involved.

Another aspect of the VRIS3 developed by the regional authorities in Värmland relates to the broad definitions of civil society, which vary across customers, consumers, users, organized groups, making it difficult to define the role of civil society in a RIS. A criticism of earlier innovation systems such as the triple helix concept has focussed on the exclusion of specific groups based on, for example gender and ethnicity. Therefore, it is essential to address this issue in relation to participation in all helices. Since the inclusion of civil society is a new aspect to consider in RIS, taking gender and ethnicity into account when including participants from the fourth helix thereby provides an opportunity to serve as a model to the other helices. We argue that it is necessary to include a broad spectrum of participants from all helices in as many of the phases of the development of the RIS as possible. The issues that are associated with the collaboration and/or the innovation process are another important aspect with regard to the development of a quadruple helix system. A number of the involved stakeholders lacked understanding of the concept of a bioeconomy as such and were also lacking the information and communication from the regional authorities that were important to create commitment. Engaging participants in as many of the phases as possible from the beginning, by setting the goals for the project, drastically improves the value of the resulting model in terms of its usefulness to decision makers, its educational potential for the public and its credibility within the community (Smith Korfmacher 2001; Beierle and Cayford 2002; Reed 2008). Therefore, it is vital to include civil society in the issue of a transformation to a forestry-based bioeconomy, given that a transformation of this kind requires a broad stakeholder involvement because of the transformation of societal functions.

This study has highlighted the importance of developing models for a quintuple helix system as a possible path to a forestry-based bioeconomy and sustainability. However, a number of issues must be resolved if the triple helix model is to be developed in practice and not only in theory. In the context of a forestry-based bioeconomy, the issues concerning a transformation of society as a whole into becoming more sustainable are broad and complex. Luyet et al. (2012) stressed the importance of identifying not only current stakeholders but also potential ones. To be able to meet future challenges and a transformation to sustainability, different kinds of knowledge are required; however, citizen-based knowledge is often seen as diffuse and difficult to embed in policy-making processes (Isenhour 2011), where current innovation policy in relation to bioeconomy is mainly used as a way of increasing economic growth and regional development (Staffas et al. 2013). However, one possible way to overcome this obstacle is to inform different stakeholders in a quadruple helix system about bioeconomy or natural resource management, which could be achieved through the 
media, town meetings, volunteer and community-oriented programmes, as well as online platforms.

The model of a quintuple helix system is represented by four stakeholder groupsacademia, industry, government and civil society - in addition to the environment in a specific place, or environmental concerns in general. Therefore, although it is mainly the first four helices that produce knowledge, the natural environment must be taken into account in the knowledge production process. The use of a quintuple helix RIS in Värmland for the transformation to a forestry-based bioeconomy could be a possible way forward towards sustainability. The model proposes the enhanced involvement of civil society in the innovation system required for a larger societal transformation aiming to change consumer behaviour as well as production patterns, technological developments and infrastructure, as norms and values. However, the involvement of civil society in the innovation system must still be regarded as a vision in regional policy documents, even though it is being investigated in collaboration with academia. Staffas et al. (2013) showed that innovation policy in Europe is mainly directed towards economic growth and not directly towards sustainability, making the process of a transformation into a forestry-based bioeconomy in Värmland an interesting issue to follow, because of the tension between economic development and sustainability. It will also be interesting to investigate similar processes in other parts of Europe where the following questions are important for the development of forms of RIS. How can co-creation and knowledge production evolve in symbiosis between society and nature in the transformation to a sustainable bioeconomy? What are the roles to be taken by different stakeholders in different types of RIS when focussing on development towards transformation to a sustainable bioeconomy?

Acknowledgments The research for this article was made possible by and financially supported by the Centre for Regional Studies (CRS) at Karlstad University, Sweden; Region Värmland, Sweden; and Vinnova through the initiative Paper Province 2.0. In developing the ideas presented here, we also thank our respondents for participating in both interviews and workshops.

Open Access This article is distributed under the terms of the Creative Commons Attribution 4.0 International License (http://creativecommons.org/licenses/by/4.0/), which permits unrestricted use, distribution, and reproduction in any medium, provided you give appropriate credit to the original author(s) and the source, provide a link to the Creative Commons license, and indicate if changes were made.

\section{References}

Alsos, G. A., Ljunggren, E., \& Hytti, U. (2013). Gender and innovation: state of the art and a research agenda. International Journal of Gender and Entrepreneurship, 5(3), 236-256.

Appelstrand, M., \& Lidestav, G. (2015). Women entrepreneurship - a shortcut to a more competitive and equal forest sector? Scandinavian Journal of Forest Research, 30(3), 226-234.

Aranguren, M. J., \& Wilson, J. R. (2013). What can experience with clusters teach us about fostering regional smart specialisation? Ekonomiaz, 83(2), 127-145.

Arnkil, R., Järvensivu, A., Koski, P., \& Piirainen, T. (2010). Exploring the quadruple helix. Report of quadruple helix research for the QLIQ project. Tampere: Work Research Centre, University of Tampere.

Arnstein, S. R. (1969). A ladder of citizen participation. Journal of the American Institute of Planners, 35(4), 216-224.

Asheim, B. (2007). Differentiated knowledge bases and varieties of regional innovation systems. The European Journal of Social Science Research, 20(3), 223-241. 
Asheim, B. T., \& Coenen, L. (2005). Knowledge bases and regional innovation systems: comparing Nordic clusters. Research Policy, 34, 1173-1190.

Beierle, T. C., \& Cayford, J. (2002). Democracy in practice. Public participation in environmental decisions. Washington: RFF Press, Resources for the Future.

Bergvall-Kåreborn, B., \& Ståhlbröst, A. (2009). Living lab: an open and citizen-centric approach for innovation. International Journal of Innovation and Regional Development, 1(4), 356-370.

Birch, K. (2012). Knowledge, place and power: geographies of value in the bioeconomy. New Genetics and Society, 31(2), 183-201.

Birch, K., Lewidow, L., \& Papaioannou, T. (2010). Sustainable capital? the neoliberalization of nature and knowledge in the European "knowledge-based bio-economy". Sustainability, 2, 2898-2919.

Bjurulf, S., \& Olsson, A. (2010). Regional innovation in Värmland. Journal of Nordregio, (1). http://www. nordregio.se/en/Metameny/About-Nordregio/Journal-of-Nordregio/Journal-of-Nordregio-2010/Journalof-Nordregio-no-1-2010/. Accessed 15 Dec 2015.

Campbell, D. F. J., Carayannis, E. G., \& Rehman, S. S. (2015). Quadruple helix structures of quality of democracy in innovation systems: the USA, OECD countries, and EU member countries in global comparison. Journal of the Knowledge Economy, 6(3), 467-493.

Carayannis, E. G., \& Campbell, D. F. J. (2009). "Mode 3" and "quadruple helix": toward a 21st century fractal innovation ecosystem. International Journal of Technology Management, 46(3/4), 201-233.

Carayannis, E. G., \& Campbell, D. F. J. (2010). Triple helix, quadruple helix and quintuple helix and how do knowledge, innovation and the environment relate to each other? A proposed framework for a transdisciplinary analysis of sustainable development and social ecology. Journal of Social Ecology and Sustainable Development, 1(1), 41-69.

Carayannis, E. G., \& Campbell, D. F. J. (2012). Mode 3 knowledge production in quadruple helix innovation systems. 21st-century democracy, innovation, and entrepreneurship for development. New York: Springer.

Carayannis, E. G., \& Rakhmatullin, R. (2014). The quadruple/quintuple innovation helixes and smart specialisation strategies for sustainable and inclusive growth in Europe and beyond. Journal of Knowledge Economy, 5(2), 212-239.

Carayannis, E. G., Barth, T. D., \& Campbell, D. F. J. (2012). The quintuple helix innovation model: global warming as a challenge and driver for innovation. Journal of Innovation and Entrepreneurship, 1(1), 1-12.

Cooke, P. (2007). To construct regional advantage from innovation platforms. European Planning Studies, 15(1), 179-194.

Dahlström, M., \& Hedin, S. (2010). Regional trajectories to the knowledge economy: Nordic-European comparisons. Oslo, Norway: Nordic Innovation Centre.

Doloreux, D., \& Parto, S. (2005). Regional innovation systems: current discourse and unresolved issues. Technology in Society, 27(2), 133-153.

Edelenbos, J., \& Klijn, E. (2006). Managing stakeholder involvement in decision making: a comparative analysis of six interactive processes in the Netherlands. Behavioral Public Administration Research and Theory, 16(3), 417-446.

Etzkowitz, H., \& Leydesdorff, L. (2000). The dynamics of innovation: from national systems and "mode 2" to a triple helix of university-industry-government relations. Research Policy, 29(2), 109-123.

European Commission. (2010). Europe 2020, a strategy for smart, sustainable and inclusive growth. Brussels: European Commission.

European Commission. (2012). Innovating for sustainable growth: a bioeconomy for Europe. Brussels: European Commission.

Flyvbjerg, B. (2003). Rationality and power. In S. Cambell \& S. S. Fainstein (Eds.), Readings in planning theory (2nd ed., pp. 318-329). Oxford: Blackwell.

Foray, D., Goddard, J., Goenaga Beldarrain, X., Landabaso, M., McCann, P., Morgan, K., Nauwelaers, C., \& Ortega-Argiles, R. (2012). Guide to research and innovation strategies for smart specialisations (RIS3). Luxembourg: European Union.

Forsberg, G. (2010). Klusterpolitik och genuskonstruktion. In G. Forsberg \& G. Lindgren (Eds.), Nätverk och skuggstrukturer i regionalpolitiken (pp. 127-132). Karlstad: Karlstad University Press.

Forsberg, G., \& Lindgren, G. (Eds.). (2010). Nätverk och skuggstrukturer i regionalpolitiken. Karlstad: Karlstad University Press.

Fuster Morell, M., \& Subirats, J. (2012). Crisis de representación y de participación. Son las comunidades virtuales nuevas formas de agregación y participación ciudadana? ARBOR Ciencia Pensamiento y Cultura, 188(756), 641-656. 
Geels, F. W. (2005). Processes and patterns in transitions and system innovations: refining the co-evolutionary multi-level perspective. Technological Forecasting \& Social Change, 72(6), 681-696.

Geels, F. W. (2010). Ontologies, socio-technical transitions (to sustainability), and the multi-level perspective. Research Policy, 39(4), 495-510.

Geels, F. W. (2011). The multi-level perspective on sustainability transitions: responses to seven criticisms. Environmental Innovation and Societal Transitions, 1(1), 24-40.

Geels, F. W., \& Schot, J. (2007). Typology of sociotechnical transition pathways. Research Policy, 36(3), 399-417.

Grundel, I., \& Dahlström, M. (2015). Transition to bio-economy, smart specialisation and quadruple helix. (policy brief 1). Karlstad: Center for Research on Region Building, Karlstad University.

Hage, M., Leroy, P., \& Petersen, A. C. (2010). Stakeholder participation in environmental knowledge production. Futures, 42, 254-264.

Healey, P. (1997). Collaborative planning: shaping places in fragmented societies. London: Macmillan.

Healey, P. (2003). Collaborative planning in perspective. Planning Theory, 2(2), 101-123.

Hock Heng, L., Mohd Othman, N. F., Md Rasli, A., \& Jawad Iqbald, M. (2012). Fourth pillar in the transformation of production economy to knowledge economy. Procedia-Social and Behavioral Sciences, 40, 530-536.

Hospers, G. (2005). 'Best practices' and the dilemma of regional cluster policy in Europe. Journal of Economic and Social Geography, 96(4), 452-457.

Hospers, G., Sautet, F., \& Desrochers, P. (2008). Silicon somewhere: is there a need for cluster policy? In C. Karlsson (Ed.), Handbook of research on innovation and clusters: cases and policies (pp. 430-446). Cheltenham: Edward Elgar.

Isenhour, C. (2011). How the grass became greener in the city: on urban imaginings and practices of sustainable living in Sweden. City and Society, 23(2), 117-134.

Ivanova, I. (2014). Quadruple helix systems and symmetry: a step towards helix innovation system classification. Journal of the Knowledge Economy, 5(2), 357-369.

Kenis, A., \& Lievens, M. (2014). Searching for the 'political' in environmental politics. Environmental Politics, 23(4), 531-548.

Leydesdorff, L., \& Etzkowitz, H. (1996). Emergence of a triple helix of university-industry-government relations. Science and Public Policy, 23(5), 279-286.

Lindberg, M. (2010). Samverkansnätverk för innovation. En interaktiv och genusvetenskaplig utmaning av innovationspolitik och innovationsforskning. Luleå: Universitetstryckeriet Luleå.

Lindberg, M., Danilda, I., \& Torstensson, B. (2012). Women resource centres - creative knowledge environment of quadruple helix. Journal of the Knowledge Economy, 3(1), 36-52.

Lindberg, M., Lindgren, M., \& Packendorff, J. (2014). Quadruple helix as a way to bridge the gender gap in entrepreneurship: the case of an innovation system project in the Baltic Sea region. Journal of the Knowledge Economy, 5(1), 94-113.

Lundvall, B. (1992). National systems of innovation. Towards a theory of innovation and interactive learning. London: Pinter.

Luyet, V., Schlaepfer, R., Parlange, M. B., \& Buttler, A. (2012). A framework to implement stakeholder participation in environmental projects. Journal of Environmental Management, 111, 213-219.

MacGregor, S. P., Marques-Gou, P., \& Simon-Villar, A. (2010). Gauging readiness for the quadruple helix: a study of 16 European organizations. Journal of the Knowledge Economy, 1(3), 173-190.

Malmberg, A., \& Power, D. (2006). True clusters, a severe case of conceptual headache. In B. Asheim, P. Cooke, \& R. Martin (Eds.), Clusters and regional development, critical reflections and explorations (pp. 50-68). London and New York: Routledge.

Martinez, D., \& Palazuelos-Martínez, M. (2015). Breaking with the past in smart specialisation: a new model of selection of business stakeholders within the entrepreneurial process of discovery. Journal of the Knowledge Economy, 1-14.

Miller, P., \& Rose, N. (2008). Governing the present: administering economic, social and personal life. Cambridge: Polity Press.

Mobjörk, M. (2010). Consulting versus participatory transdisciplinarity: a refined classification of transdisciplinary research. Futures, 42(8), 866-873.

Mouffe, C. (2008). Om det politiska. Stockholm: Tankekraft Förlag.

Nählinder, J. (2012). Vi tar höjd för innovationerna: att förstå innovationer i kommunal sektor. HELIX working papers, ISSN 1654-8213 12:3). Linköping: Linköpings Universitet.

Organisation for Economic Co-operation and Development. (2009). The bioeconomy to 2030: designing a policy agenda. Paris: OECD. 
Pettersson, K. (2007). Men and male as the norm?: a gender perspective on innovation policies in Denmark, Finland and Sweden. Copenhagen: Nordiska Ministerrådet, NordRegio.

Porter, M. E. (2000). Locations, clusters, and company strategy. In G. L. Clark, M. P. Feldmann, \& M. S. Gertler (Eds.), The Oxford handbook of economic geography (pp. 253-274). Oxford: Oxford University Press.

Reed, M. S. (2008). Stakeholder participation for environmental management: a literature review. Biological Conservation, 141, 2417-2431.

Region Värmland (2015). Värmland's research and innovation strategy for smart specialisation 2015-2020. http://www.regionvarmland.se/wp-content/uploads/2016/02/VRIS3.pdf. Accessed 29 May 2016.

Rogers, M., \& Shoemaker, F. (1971). Communication of innovations; a cross-cultural approach. New York: The Free Press.

Säll, L. (2011). Kluster som teori och politik; om den regionala tillväxtpolitikens diskursiva praktiker. Diss. Karlstad University Press: Fakulteten för samhälls-och livsvetenskaper, statsvetenskap.

Sassen, S. (2013). When territory deborders territoriality. Territory, Politics, Governance, 1(1), 21-45.

Smith Korfmacher, K. (2001). The politics of participation in watershed modeling. Environmental Management, 27(2), 161-176.

Staffas, L., Gustavsson, M., \& McCormick, K. (2013). Strategies and policies for the bioeconomy and bio-based economy: an analysis of official national approaches. Sustainability, 5(6), 2751-2769.

Swedish Energy Agency, Vinnova, \& The Swedish Research Council for Environment, Agricultural Sciences and Spatial Planning (2012). Swedish research and innovation strategy for a bio-based economy. http://www.formas.se/PageFiles/5074/Strategy_Biobased_Ekonomy_hela.pdf. Accessed 15 Dec 2015.

Swyngedouw, E. (2005). Governance innovation and the citizen: the Janus face of governance-beyond-thestate. Urban Studies, 42(11), 1991-2006.

United Nations. (2015). Transforming our world: the 2030 agenda for sustainable development (A/RES/70/1). Paris: United Nations.

Vinnova. (2014). VINNVÄXT. A programme renewing and moving Sweden ahead. Regional growth through dynamic innovation systems. Vinnova information (VI 2014:04). Stockholm: Vinnova.

von Hippel, E. (2005). Democratizing innovation: the evolving phenomenon of user innovation. Journal für Betriebswirtschaft, 55(1), 63-78.

Wallin, S. (2010). The co-evolvement in local development-from the triple to the quadruple helix model. Conference Paper at Triple Helix VIII. Madrid

Westlund, H. (2006). Social capital in the knowledge economy-theory and empirics. Berlin and Heidelberg: Springer.

Yang, Y., \& Holgaard Egelund, J. (2012). The important role of civil society groups in eco-innovation: a triple helix perspective. Journal of Knowledge-based Innovation in China, 4(2), 132-148. 